\title{
Circular Economy as a Catalyst for Progress towards the Sustainable Development Goals: A Positive Relationship between Two Self-Sufficient Variables
}

\author{
Juan-Manuel Valverde * and Carmen Avilés-Palacios (D) \\ Escuela Tecnica Superior de Ingenieria de Montes, Forestal y del Medio Natural, Universidad Politecnica de \\ Madrid, Jose Antonio Novais, 10, 28040 Madrid, Spain; carmen.aviles@upm.es \\ * Correspondence: jm.valverde@upm.es; Tel.: +34-910671632
}

check for

updates

Citation: Valverde, J.-M.;

Avilés-Palacios, C. Circular Economy as a Catalyst for Progress towards the Sustainable Development Goals: A Positive Relationship between Two Self-Sufficient Variables. Sustainability 2021, 13, 12652. https://doi.org/ $10.3390 /$ su132212652

Academic Editors: Anna Mazzi, João Carlos de Oliveira Matias and Paolo Renna

Received: 13 September 2021 Accepted: 11 November 2021 Published: 16 November 2021

Publisher's Note: MDPI stays neutral with regard to jurisdictional claims in published maps and institutional affiliations.

Copyright: (c) 2021 by the authors. Licensee MDPI, Basel, Switzerland. This article is an open access article distributed under the terms and conditions of the Creative Commons Attribution (CC BY) license (https:// creativecommons.org/licenses/by/ $4.0 /)$.

\begin{abstract}
Governments, civil society organisations and companies have expressed an interest in contributing to the achievement of the Sustainable Development Goals, but incorporating these goals into their strategies and activities is not an easy task. This study aims to provide information on the role of circular economy as a tool to boost progress towards the Sustainable Development Goals to assist these different stakeholders in their quest to attain the goals. Using heuristic methodology, a review of the existing literature was conducted to explore the relationship between the two terms. Specific attention was paid to the development goals with the highest interdependence with circular economy: Sustainable Development Goal 6 (Clean Water), 8 (Decent work), 12 (Responsible consumption and production) and 15 (Life on land). Having identified the reciprocal relationships between the two variables, the results of the literature review were then analysed to explore their possible self-sufficiency. The findings of the study are intended to assist stakeholders in incorporating the SDGs into their corporate sustainability strategies.
\end{abstract}

Keywords: circular economy; sustainable development goals; sustainability

\section{Introduction}

Deforestation, energy deficit, biodiversity loss, poverty and inequality are just a few of the many issues threatening the planet's sustainability [1-3]. Natural resources are limited, and waste produced by increasing consumption of non-renewable energy and raw materials is jeopardising the ecosystem's capacity for absorption [4], with many studies pointing to human activity as the cause of these issues [5-7]. Given that in 2014 the regenerative capacity of 1.5 planet Earths was required to supply the natural resources we use annually [8] and that the global population and levels of consumption are currently rising, it is clear that improving the efficiency of our resources use is now a priority [9].

Because human activity is the main cause of the problem, society must seek to resolve these conflicts by reworking the current production model and market economy in an intelligent and sensitive manner [10]. A number of measures have been taken by institutions, societies and organisations in an attempt to address the issue and achieve more sustainable development, defined in the Brundtland report as "development that meets the needs of the present without compromising the ability of future generations to meet their own needs" [11]. There are multiple strategies linked to this goal, but only the Sustainable Development Goals (SDGs) and their 2030 Agenda, Transforming our World [12], have the necessary impact to bring about the global changes required. Nevertheless, this overarching framework must be supplemented by strategies to ensure greater involvement from organisations in initiatives aimed at achieving sustainable development, as well as to implement economic and production models that facilitate this form of development. In this regard, circular economy may be viewed as one of the most relevant models in achieving systemic change. 
The term 'circular economy' has many definitions, but we have selected just one in order to properly delimit the scope of our analysis. The chosen definition was developed by Kirchherr, Reike and Hekkert after analysing 114 different definitions, and the following was concluded [13]:

"A circular economy describes an economic system that is based on business models which replace the 'end-of-life' concept with reducing, alternatively reusing, recycling and recovering materials in production/distribution and consumption processes, thus operating at the micro level (products, companies, consumers), meso level (eco-industrial parks) and macro level (city, region, nation and beyond), with the aim to accomplish sustainable development, which implies creating environmental quality, economic prosperity and social equity, to the benefit of current and future generations. It is enabled by novel business models and responsible consumers."

Due to the fact that circular economy should be the economic model to be followed, it should also be seen as a tool to achieve sustainable development, which has been described as economic development compatible with a sustainable future. The framework to achieve this is included in Agenda 2030, using the Sustainable Development Goals [11,13].

Viewing the Sustainable Development Goals as a key driver of change for use by public authorities, companies and citizens in achieving sustainable development, and aiming to highlight the factors that are helpful in attaining these goals, this study explores circular economy and literature relating it to the SDGs in depth to identify evidence that confirms or denies the existence of a qualitative relationship between implementation of circular economy and the attainment of the Sustainable Development Goals.

In terms of structure, the first part of this paper sets out the study objectives and methodology before systematising our observations and findings in two sections. The first section describes the literature, highlighting the relationship between the study variables (SDGs and CE), before considering the SDGs that are most directly impacted by the implementation of circular economy in greater depth. The second section presents the findings from a new line of qualitative analysis, identified following evaluation of our study context. This evaluation suggests that the study should not be limited to the presence of a relationship between the variables and that the extent to which these variables are self-sufficient should also be explored. Self-sufficiency is understood here as the autonomy of each variable's behaviour, regardless of the evolution of the other variable, in the sense of being independent or not contingent. Finally, a summary of the most relevant findings on the links between the Sustainable Development Goals and circular economy is provided for use by stakeholders attempting to implement the SDGs.

\section{Objectives}

The primary objective of this study is to conceptually establish the relationship and selfsufficiency existing between implementation of a circular economy and progress towards the SDGs to allow stakeholders to make decisions regarding the consequences that different actions involved in the transition towards a circular economy will have on attainment of CSR components and the Sustainable Development Goals. Circular economy may be viewed as an additional tool for use in working towards the Sustainable Development Goals. With this objective in mind, two working hypotheses were identified:

- The SDGs and CE are interlinked. The study of the relationship between these two qualitative variables is of central importance when interpreting research results. In this study, it is based not on statistical analysis (measuring trends in the evolution of numeric variables) but on an analysis of the synergistic relationship between the SDG targets and the pillars of circular economy.

- The SDGs and CE are self-sufficient. The study also aims to demonstrate the selfsufficiency of these two variables, analysing the way in which the behaviour of one variable, the SDGs, is not necessarily affected by the circumstances and values surrounding $\mathrm{CE}$. 


\section{Methods}

On the basis that there is no single scientific method but rather various scientific ways of obtaining an understanding of reality, a methodology based on heuristics developed by Polya was selected $[14,15]$. Under this qualitative methodology, an analysis of the information collected serves as a basis for suggesting hypotheses or addressing the research question: is there a positive relationship between implementation of a circular economy and the Sustainable Development Goals?

Following this methodology, our analysis encompasses the following steps [15]:

- Firstly, the research question is identified: to determine the relationship between $\mathrm{CE}$ and progress towards the SDGs.

- Secondly, connections between the study variables are identified through a review of the current literature on the SDGs and their links to circular economy. This will enable the identification of practical cases which show the relationship between the study variables.

- Thirdly, the links between the study variables will be identified using a table, enabling the relationship between CE and each of the SDG targets to be observed at a glance.

- Finally, the findings will be reviewed and discussed to consolidate progress and reinforce the results of the study.

\section{Relationship between CE and SDGs}

An analysis of the literature concerning the two variables and the possible links between them clearly shows the existence of a positive relationship between the implementation of a circular economy and the SDGs. In this paper, the term correlation does not imply a statistical correlation, but a strong conceptual relationship between terms. This is summarised in Table 1, which presents an analysis of the most representative texts describing the SDGs and circular economy, as well as the relationship between them.

Table 1. Reports on the relationship between CE and SDG.

Author Document Text

Generally speaking, the impact of the transition to a new circular model will have a positive impact on all SDGs, either directly or indirectly. These include SDG 6 (Clean Water and Sanitation), SDG 9 (Industry, Innovation and Infrastructure), SDG 11 (Sustainable Cities and

Asociación de Usuarios de Bancos, Cajas y Seguros (ADICAE) [16]

La Economía Circular en el Sector Communities), SDG 13 (Climate Action), SDG 14 (Life below Water), SDG 15 (Life on Land) and SDG 17 (Partnerships for the Goals). The potential of circular economy as a tool for achieving the targets proposed as part of the SDGs is unquestionable.

The 2013 and 2014 Annual Growth Surveys stressed the job creation potential of the green economy and the need

European Commission [17]

Green Employment Initiative

Towards the Circular Economy: Accelerating the Scale-up across Global Supply Chains
World Economic Forum [18] to develop strategic frameworks in which labour market and skills policies play an active role in supporting job creation.

For governments, this shift to circular economic activity could help address the global job gap of 600 million that the International Trade Union Confederation forecasts by 2030 if business as usual continues. 
Table 1. Cont.

\begin{tabular}{cc}
\hline Author & Document \\
\hline Phillips & Towards the Circular Economy: \\
{$[18]$} & Accelerating the Scale-up Across \\
& Global Supply Chains
\end{tabular}

UN Sustainable Development Goals Partnership Platform [19]

European Commission's ‘Circular Economy Action Plan'
Philips says they can reach more customers if they retain ownership of the lighting equipment as customers do not have to pay high upfront costs, and Philips ensures the sound environmental management of end-of-life lighting equipment. This is a new way for customers to achieve their sustainability goals.

The European Commission's circular economy strategy benefits and supports the achievement of several Sustainable Development Goals, including SDG 6 on energy, SDG 8 on economic growth, SDG 11 on sustainable cities, SDG 12 on sustainable consumption and production, SDG 13 on climate change, SDG 14 on oceans and SDG 15 on life on land.

This action plan will be instrumental in reaching the Sustainable Development Goals (SDGs) by 2030, in particular Goal 12 of ensuring sustainable consumption and production patterns.
Closing the loop-An EU action plan for the Circular Economy
[20]

European Academies Science Advisory Council [21]
Circular Economy: A

Commentary from the Perspectives of the Natural and Social Sciences
These considerations suggest that circular economy should not be considered as a local circular economy and that the aim should be global circularity. In parallel with EU-wide measures, the concept should therefore be encouraged internationally (including through the United Nations Sustainable Development Goals fora)

The potential impact of a circular economy on international competitiveness is also considered. There is potential for improved competitiveness and new
European Academies Science Advisory Council [21]
Circular Economy: a Commentary from the Perspectives of the Natural and Social Sciences markets, but there are also potential disadvantages from an economic theory perspective where policies for a circular economy are applied only within the European Union. It is thus important to ensure that these policies are also fully embraced in international trade negotiations, and the United Nations policy process involving Sustainable Development Goals.

This project included the largest academic meta-study to date on the relationship between employment and circular economy. The review of 65 academic studies indicates that, while more research is needed, "existing studies point to the positive employment effects occurring in the case that a circular economy is implemented."
Within: a Circul Economy Vision for a Competitive Europe.
We hope that this report can provide input for the Commission's new proposal, particularly in terms of recognizing circular economy as a key instrument for Mr. Juncker's competitiveness and jobs agenda.

The Commission places circular economy indicators in the context of sustainable development goals, specifying that "This action plan will be instrumental in reaching the Sustainable Development Goals (SDGs) by 2030". Indeed, as pointed out in our earlier statement, circular economy is a means to enhancing sustainable wellbeing, rather than being an end in itself (EASAC, 2015) and is thus closely connected with SDGs. 
Table 1. Cont.

\begin{tabular}{cl}
\hline Author & \multicolumn{1}{c}{ Document } \\
\hline $\begin{array}{c}\text { European Academies Science } \\
\text { Advisory Council [24] }\end{array}$ & $\begin{array}{l}\text { Owing to the linkages between circular economy, } \\
\text { human well-being and sustainable development, the } \\
\text { indicators for monitoring progress towards a more } \\
\text { circular economy can be included in the wider debate on } \\
\text { developing alternatives to gross domestic product } \\
\text { (GDP), where the Commission's circular economy } \\
\text { indicators, 'Beyond GDP', sustainable development } \\
\text { indicators and environmental pressure index actions are } \\
\text { involved. }\end{array}$ \\
&
\end{tabular}

The Sustainable Development Goals (SDGs) have set an ambitious agenda for society, government and business. Water has a dedicated goal in SDG 6 (ensure availability

International Water Association [25]

Water Utility Pathways in a Circular Economy and sustainable management of water and sanitation for all), and its attainment will be reliant upon contributing to and benefiting from the attainment of other SDGs, most notably in the context of circular economy, SDG 12 (ensure sustainable consumption and production patterns).

The author argues that circular business models do not

Mateusz Lewandowski [26]

Spanish Government 2030 Agenda [27]

Schroeder; Anggraeni; Weber [28] Danuta Lipińska [29] The Water-wastewater-sludge Sector and the Circular Economy
Designing the Business Models for Circular Economy-Towards the Conceptual Framework
Plan de Acción para la Implementación de la Agenda 2030: Hacia una Estrategia Española de Desarrollo

The Relevance of Circular Economy Practices to the Sustainable Development Goals necessarily aim to balance ecological, social and ecological needs, in contrast to business models, although at the same time they can serve sustainability goals.

The plan identifies priority areas for action in which 'leverage' policies should be introduced: preventing and fighting poverty and social exclusion, circular economy and social economy.

The paper concludes that CE practices can be applied as a "toolbox" and be specific implementation approaches for achieving a sizeable number of SDG targets.

The objective of this paper is a theoretical and empirical analysis and evaluation of the role, importance and opportunities of the water-sewage-sludge industry in the implementation of a circular economy. The results of the study show that there are significant links between the development goals of the water-sewage-sludge sector and circular economy.

Achieving sustainable consumption and production will deliver not only Sustainable Development Goal 12, but simultaneously contribute significantly to the achievement of almost all of the Sustainable Development Goals, directly or indirectly. To demonstrate the impacts of sustainable consumption and production and its role in addressing key environmental and social challenges effectively, the One Planet network will jointly address, across programmes, strategic cross-cutting topics or themes-which include small and medium enterprises, waste, plastics, circular economy, behavioural insights and lifestyles, and innovation-to enable a strategic channelling of efforts and provide a unified vision. 
Table 1. Cont.

\begin{tabular}{ccc}
\hline Author & Document & Text \\
\hline $\begin{array}{c}\text { Federación Española de } \\
\text { Municipios y Provincias. FEMP } \\
\text { [31] }\end{array}$ & $\begin{array}{c}\text { Hacia una Estrategia Local de } \\
\text { Desarrollo Sostenible }\end{array}$ & $\begin{array}{l}\text { In 2015, the United Nations presented the 2030 Agenda } \\
\text { for Sustainable Development, featuring 17 Sustainable } \\
\text { Development Goals (SDGs). The Action Plan for } \\
\text { Implementation of the 2030 Agenda: Towards a Spanish } \\
\text { Sustainable Development Strategy, highlights circular } \\
\text { economy as a 'leverage policy' or a key area for } \\
\text { accelerating implementation of the SDGs. }\end{array}$ \\
$\begin{array}{c}\text { Ministry for the Ecological } \\
\text { Transition }\end{array}$ & $\begin{array}{l}\text { With a view to fulfilling the 2030 Agenda, the Council of } \\
\text { [32] }\end{array}$ & $\begin{array}{l}\text { Ministers approved the Action Plan for Implementation } \\
\text { of the 2030 Agenda in June 2018. Within this context, the } \\
\text { Spanish Circular Economy Strategy has been identified } \\
\text { as a key element in achieving several SDGs on the 2030 } \\
\text { Agenda in Spain. }\end{array}$ \\
\hline
\end{tabular}

Many organisations have reported on the relationship between the two concepts [20,31], confirming that implementation of $\mathrm{CE}$ has a positive impact on the achievement of the SDGs, providing employment, encouraging innovation, creating a competitive advantage for companies and protecting the environment $[16,19]$.

The European Commission was the first to discuss circular economy in relation to sustainability, noting that the action plan for the CE must serve as a tool for achieving the Sustainable Development Goals by 2030 [20]. CE has also been identified as one of the leverage policies needed as part of a Spanish sustainable development strategy [27].

The fact that humans will require three planet Earths to meet their needs by 2050 [32] points to circular economy and the SDGs as key components of sustainability and highlights the need for a shift in the production model from the current linear system to a circular economy [22] in which efficient use of resources is a priority [33].

One of the most relevant studies concerning the relationship between the study variables was conducted by Schroeder, Anggraeni and Weber and analysed the extent to which circular economy practices are relevant to the implementation of each of the 169 targets that make up the SDGs [28].

Based on this study, we produced our own model, whose aim is to provide stakeholders with a tool allowing them to identify the actions relating to circular economy with the greatest impact on the achievement of the SDGs. (Figure 1). It enables the visualization and facilitates the interpretation of two of the study's conclusions:

- Identification of the degree of relationship between the SDG targets and CE.

- Grouping of the SDGs according to the main CSR pillars (social, economic and environmental).

The contribution of CE to each of the 169 targets for the SDGs can be visualised at a glance according to the five types of relationship identified in Schroeder, Anggraeni and Weber's report:

- Direct contribution, entailing significant cooperation between $\mathrm{CE}$ and achievement of the SDGs.

- Indirect contribution, indicating the presence of synergies between different goals as a result of CE practices.

- Reverse causality, i.e., achievement of the target contributes to implementation of CE.

- No link or connection between implementation of CE and achievement of the SDGs.

- Some targets for the goal offer opportunities for cooperation with CE practices. 


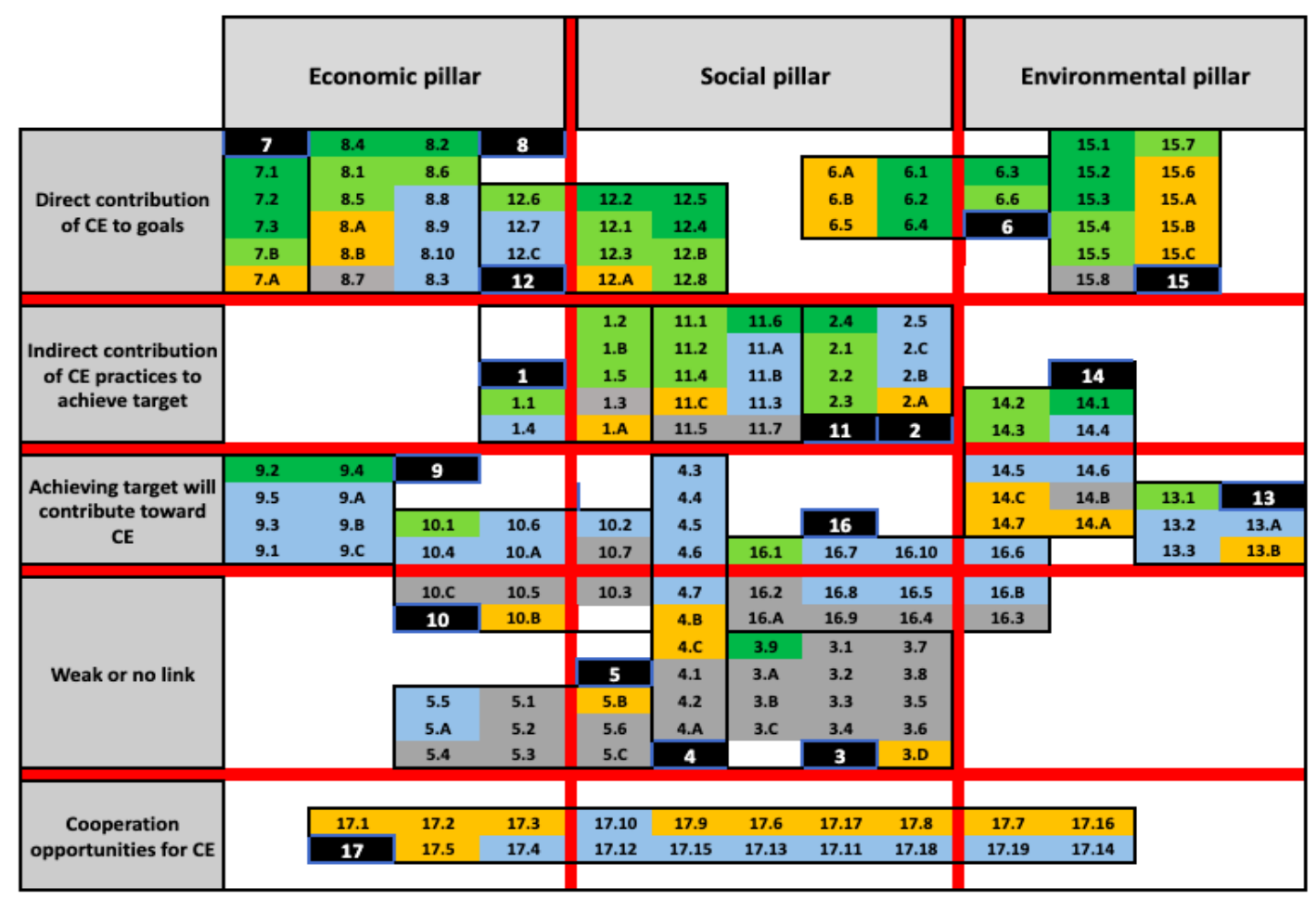

Figure 1. Visualization of the impact of CE implementation for each SDG target according to the three CSR pillars panel.

Figure 1 allows the various SDGs associated with the pillars of corporate social responsibility (CSR) and the degree of relationship between CE and the SDGs, broken down into their respective targets, to be identified at a glance. The dark green colour indicates a direct contribution, the light green an indirect contribution, the blue a reverse contribution, whereby the SDGs help to make CE a reality, and the orange shows the presence of opportunities for cooperation. The grey colour on some of the targets indicates the absence of any link between the variables.

The degree of relationship between the 169 targets and CE, as well as the corresponding CSR pillar, may be observed from the table. This will allow stakeholders with an interest in implementing the SDGs to see how circular economy can serve as a tool in their quest for social, economic and environmental wellbeing.

The presence of this positive relationship has resulted in many of the indicators used to measure CE being adopted by the European Commission to monitor progress towards the SDGs. By way of example, several of the indicators found in official databases are listed below [34]. Clear links to circular economy can be seen in line with the areas of reference proposed by Schroeder, Anggraeni and Weber [28] (Table 2).

Some of these indicators are linked to security in the supply of essential raw materials, while others relate to repair and reuse, waste generation and management and trading in secondary raw materials which are recycled in the EU, but they all demonstrate that $\mathrm{CE}$ and its indicators are now being used by the institutions in their work towards the Sustainable Development Goals [24].

Drawing on the relationship identified between CE and the SDGs according to the connections observed in the study by Schroeder, Anggraeni and Weber (SDG 6, 7, 8, 12, 15) [28] and the practices recommended by the United Nations (SDG 6, 8, 11, 12, 13, 14, 15) [19], this paper will now focus on SDGs 6, 8, 12 and 15, which are the goals most impacted by the implementation of CE. This will enable stakeholders to identify where to focus their efforts in order to meet their targets. 
Table 2. Relationship between official indicators used to measure SDGs and the pillars of circular economy.

\begin{tabular}{|c|c|c|}
\hline SDG & Key CE Element & SDG.org Indicators \\
\hline 6 & Water and Sanitation & $\begin{array}{c}\text { Proportion of safely treated domestic } \\
\text { wastewater flows }(\%)\end{array}$ \\
\hline 8 & $\begin{array}{l}\text { Recycling of Municipal } \\
\text { Household Waste and } \\
\text { E-Waste }\end{array}$ & $\begin{array}{l}\text { Electronic waste generated, per capita } \\
\qquad(\mathrm{Kg})\end{array}$ \\
\hline 12 & $\begin{array}{c}\text { Remanufacturing, Repair and } \\
\text { Refurbishment }\end{array}$ & $\begin{array}{l}\text { Countries with policies, instruments and } \\
\text { mechanisms in place for sustainable } \\
\text { consumption and production }\end{array}$ \\
\hline 15 & Industrial Symbiosis & $\begin{array}{l}\text { Countries with biodiversity values } \\
\text { integrated into national accounting and } \\
\text { reporting systems, defined as } \\
\text { implementation of a system of } \\
\text { environmental-economic accounting }\end{array}$ \\
\hline
\end{tabular}

\subsection{Clean Water and Sanitation, SDG 6}

Circular economy, based on principles such as transforming waste into resources and extending the useful life of elements such as water [35], is a key pillar in achieving SDG 6 because $40 \%$ of the world's population is seriously affected by water scarcity [36]. The situation is still more serious given that global demand for water has been rising by $1 \%$ per year since the early 1980s and is set to increase by up to $30 \%$ of current demand according to estimates for 2050 [37].

Therefore, the treatment of wastewater as an alternative source of water under a circular economy offers great potential for addressing the issue, by increasing the supply of available water in the future through recycling and reuse (SDG 6.3) [38].

From agricultural irrigation to industrial use, wastewater treated to the required standard is part of the hydrological cycle, and its use would contribute to increasing the necessary water supply by improving circularity in treatment processes. A number of measures to encourage the use of treated wastewater were proposed by the EU in its action plan for a circular economy, 'Closing the loop' [20].

Closing the loop in terms of water reuse may lead to significant social, environmental and economic benefits, boosting efficiency in the use of water resources (SDG 6.4) and achieving universal access to water (SDG 6.1). These benefits include [39]:

- Increased water availability;

- More holistic, sustainable use of water resources;

- Less overexploitation of surface water;

- Less energy used than in underground water resources;

- Lower agricultural production costs and increased yields;

- Greater local employment opportunities in tourism and agriculture, among other sectors.

Water reuse is directly linked to CE because it extends the life cycle of water use, increases its productivity and reduces waste, as well as recovering materials in the form of nutrients [32].

The transition to a circular economy combining more efficient water use with incentives for innovation in the sector will help to address the growing imbalance between water supply and demand [40,41]. Incentives for innovation will be key as the cost of meeting the targets relating to water exceeds USD 100 billion per year [42]; every effort must be made to reduce these costs. 
The literature reviewed here shows how the transformation from a linear to a circular system involving water reuse, among other measures, represents an opportunity to boost progress towards the water-related Sustainable Development Goals [25,29,43].

\subsection{Decent Work and Economic Growth, SDG 8}

Circular employment may be defined as any activity involving an individual in any of the components of circular economy. It is estimated that more than 3.4 million people currently work in the circular economy field in Europe [44]. From 2002 to 2011, employment in the environmental sector rose constantly. Even during the recession, a growth rate of around $20 \%$ was estimated, creating around 1.2 million more jobs [17].

In the case of SDGs relating to economic growth, circular economy plays a clear role in boosting employment (SDG 8.5), and the implementation of this economy is predicted to contribute EUR 600 million by 2030, helping to close the labour gap [18].

This growth in the labour market is expected to continue because circular economy is a labour-intensive model, unlike the linear model with its focus on resource use [45]. Therefore, a circular economy will provide employment for young people without studies or training (SDG 8.6).

After analysing more than 65 studies on the subject, France Stratégie reports that implementation of CE will have a positive effect on employment, especially in low-skilled sectors, as well as boosting countries' GDP (SDG 8.1) [46]. In the case of the European Union, up to $7 \%$ more growth is predicted by 2030 in comparison with the current model [22].

This shows that, without the contributions made by circular economy, improving resource efficiency and reducing resource volatility and prices, the current production model may even hinder growth [47].

A shift to a circular economy will benefit certain sectors, such as transportation, agriculture, construction and waste recovery and recycling, but there can be no doubt that digitalisation, which has doubled in size over the last 20 years [22], will be one of the sectors most positively affected by the rise of CE.

The new business models emerging in relation to circular economy, such as those transforming the generation of products into services (product-service systems, or PSS), will bring about economic growth as well as an increase in the use of capital goods and environmental improvements as a result of lower resource use and increased efficiency [48]. These new models will help to decouple economic growth from resource use (SDG 8.4), which is also one of circular economy's pragmatic goals [49].

Greater collaboration between industry and local communities may also reduce waste and increase resource efficiency through corporate synergies and the power of proximity, as demonstrated by the industrial symbiosis present at sites such as the Kalundborg Eco-Industrial Park in Denmark [50,51].

Therefore, the literature review shows that achievement of the SDGs relating to growth and employment is directly correlated with the implementation of a circular economy [51]. According to the Green Employment report, the implementation of current legislation on waste prevention and management alone will create 400,000 new jobs in Europe [17].

\subsection{Responsible Production and Consumption, SDG 12}

Although all the Sustainable Development Goals are highly relevant, those relating to responsible production and consumption are particularly important because any improvements made in optimising resources use may be jeopardised by the knock-on effects arising from increased consumption [52].

With this in mind, many organisations are working to trigger a more rapid shift towards sustainable consumption patterns [30-32], encouraging reduction, reuse, repair and recycling, which are among the pillars underpinning CE and play a clear role in reducing waste generation and stimulating efficient resource use (SDG 12.2 and SDG 12.5) [32]. 
With regard to the reduction in food waste stipulated in SDG 12.3, a circular economy provides a boost for new entrepreneurial opportunities and business models that show that eliminating food waste is economically viable if products discarded for their imperfections or for aesthetic reasons are reintroduced into the market, as retailers often accept only $60-80 \%$ of products from farmers [53].

By improving the way in which we produce and consume (SDG 12.1), circular economy represents the antithesis of current consumption patterns and has a fundamental role to play [54]. Circular economy not only inspires new economic systems, it also encourages a deeper understanding among consumers of the circumstances surrounding products and mediates processes transforming their consumer behaviour [55]. This support will be essential, because a lack of support for demand is one of the main barriers preventing companies from adopting more sustainable models [56].

As a result, many scholars have raised the need to address the issue from the demand side and focus primarily on the implications of consumption rather than production in discussions regarding diversifying and expanding the implementation of a circular economy $[57,58]$.

Strategies used to encourage circular consumption with a positive impact on attainment of the Sustainable Development Goals (such as ensuring that people have information regarding sustainable products and lifestyles, SDG 12.8), include [55]:

- Implementation of circular business models;

- Use of design in addressing psychological factors that trigger circular behaviours;

- Communication as a marketing tool for increasing the model's implementation capacity.

Despite consumption serving as a basis for encouraging sustainable behaviour, circular economy cannot only drive progress towards achieving the goals in this manner. Initiatives on the supply side are also important, such as:

- Transitioning towards sustainable business models incorporating the triple bottom line (economic, environmental and social outcomes) into their objectives [59];

- Creating circular business models introducing the 'take back system' into their canvas methodology [26];

- Implementing product-service systems (PSS) with a direct impact on consumer responsibility in terms of looking after products and minimising environmental costs [60].

Besides its specific contribution in relation to consumption and production, there are two key scenarios in which a CE can accelerate achievement of SDG 12 . On the one hand, in its attempt to implement sustainability within the corporate sector (12.6), where collaboration between different stakeholders provides evidence of efforts to boost sustainability in the private sector [22,61]. On the other hand, the involvement of public institutions in stimulating public procurement (also known as circular procurement), which emerged as a key tool in [62,63].

These considerations point to a direct, positive relationship between progress on improvements to responsible production and consumption and the implementation of a circular economy [64].

\subsection{Life on Land, SDG 15}

Recently, circular economy has begun to be viewed as a method for improving environmental sustainability [65]. One of the reasons for this is that it seeks to decouple rising waste generation from growth in indicators such as GDP [62], with a positive impact on reducing resource use, increasing efficiency in the use of products already in the production cycle, and improving environments on land and their ecosystems.

Protecting these ecosystems is also made easier by the measuring process established as one of the principles of circular economy. Using scientific tools, such as life-cycle assessment (LCA), awareness of the impact of changes to the environment as a result of 
human activity is an inherent part of circular economy, prompting improved protection of environments, crops and forests [66].

Specific planning for the agri-food and forestry sectors, such as integrating ecosystem and biodiversity values into national and local planning (15.9), which are listed in the Spanish Circular Economy Strategy as a priority sector for action, also provides support for targets [33].

Support for targets relating to soil degradation, as in SDG 15.3, is also provided by several areas for action promoted as part of CE, such as carbon sequestration in soils [67]. This initiative, based on conservation agriculture, which enhances soil quality and organic matter content, is supported by $\mathrm{CE}$ in the following ways [3]:

- Higher yields;

- Improved food security, especially during droughts;

- Lower costs;

- Easier distribution of labour needs.

CE makes an even more significant contribution to the SDGs when we consider that soil is the second largest natural carbon sink after the oceans [68]. CE being applied to agriculture through the concept of regeneration also encourages the reincorporation of waste and sub-products into the value chain. Practices such as composting result in nutrients being reincorporated into the soil, reducing the need for chemical fertilisers, among other benefits [69]. However, there is a need of new and deeper findings on other issues regarding the development of new sustainable value chains in the agro-forestry sector.

Another historic concept that precedes and forms part of circular economy - biomimicryis indicative of the concept's alignment with the goals to protect biodiversity. This new science, which studies models found in the natural world and imitates their designs and processes to address human problems, goes hand-in-hand with the Sustainable Development Goals $(15.1,15.2,15.5,15.7)$ because it aims to create a mature ecosystem able to provide sufficient resources [70].

Alongside other positive impacts such as preventing deforestation, optimising the water cycle and eliminating waste, among others, there is a positive, direct link between achievement of the Sustainable Development Goals and implementation of circular economy.

\section{Self-Sufficiency of CE and the SDGs}

Although the principal line of the study focusses on the existence of a qualitative relationship between the SDGs and CE, after observing the results of the study and taking the scientific method used into consideration, we decided to explore the possible selfsufficiency of the two variables of study. In this regard, extending the initial study objectives, this section will present the three main findings that confirm the self-sufficient nature of the two variables (SDGs and CE).

Firstly, it was observed that the term 'circular economy' does not feature in the 2030 Agenda for Sustainable Development [12], demonstrating the autonomy of the SDGs with regard to the CE from the perspective of the United Nations. The same is true of the monitoring reports produced by the United Nation, which do not make any mention of circular economy as a tool for achieving the SDGs [70-74].

Secondly, though they may appear to share similar goals, the SDGs set out a series of goals in favour of people and the planet [12], while circular economy seeks a change of production model based on preserving products, components and materials over time [22]. Therefore, CE focuses more closely on the production model and the changes that must be made to it, as its priority is to extend the life cycle of the resources used and boost their circularity $[75,76]$. On the other hand, most of the targets linked to the SDGs focus on social aspects. This could change in the future with the evolution of the CE concept, but more social practices are not currently key components of business models based on CE. This 
explains the clear absence of relationships identified in the social aspects evaluated in this study [28].

Finally, an analysis of the historical origin of the concept also demonstrates the selfsufficiency of CE in relation to the SDGs, showing how the term 'circular economy' evolved from concepts dating back much further than the SDGs, such as:

- Industrial symbiosis, which emerged after the Industrial Revolution (18th century) and is based on the internalisation of negative externalities by businesses by recovering waste and transforming it into resources [77];

- Permaculture (1978), which aims to reduce the use of polluting, energy-intensive industrial technologies by designing landscapes that imitate the natural world to supply food and energy to meet local needs [78,79];

- Biomimicry (1974), which seeks inspiration from the natural world, imitating its forms and aiming to copy its ecosystems as a whole [70].

It is important to bear in mind, then, that the line linking the SDGs and CE is a fine one and that, although environmental improvements are a basic premise of the SDGs, circularity is not necessarily equivalent to environmental sustainability in every aspect. Therefore, it is important for the concept of $\mathrm{CE}$ to be reworked to acknowledge the reality that closed-loop recycling is not always more beneficial than open-loop recycling and that remanufacturing is not always preferable to recycling from an environmental perspective [80].

These findings emphasise the unique identity of each of the study variables and highlight the need for further research into the synergies involved in their implementation, taking the fact that both variables can evolve independently of one another into consideration.

\section{Conclusions}

After analysing the literature concerning the study variables and the links between them, it is clear that there is a qualitative and positive relationship between implementation of a circular economy and the SDGs.

This study views circular economy as a powerful tool that may be leveraged to attain the SDGs, because the development of a new production model in which resources are more valued contributes to the achievement of many of the SDG targets. Although this study focuses primarily on the influence of CE on the SDGs, the relationship works in both directions, and the SDGs may also make a significant contribution to the new production model sought under CE [28].

It is important for stakeholders to know how to take advantage of the implementation of $\mathrm{CE}$ in their work towards the SDGs, because both variables advocate the need for collaboration by different stakeholders as part of their vision of change. The table presented in Figure 1 will allow these groups to see at a glance which of the goals will be most positively influenced by the implementation of a CE.

The two variables both advocate political action [32] but they also accord significant responsibility for managing the changes to be made by the population, and especially by companies $[81,82]$.

New rules must be set in the current market economy in order to implement the principles of CE and the SDGs and preserve the environment for future generations, indicating the need for both concepts to be implemented simultaneously [22].

The links between CE, human wellbeing and sustainable development give rise to a broader debate in economics, and in the European Commission more specifically, as to whether these indicators should be included when developing alternatives to GDP [23,24]. As a result, the Commission has undertaken to present an effective monitoring framework encompassing a series of key indicators that capture the main components of circular economy in its reports on the SDGs. 
Our findings provide stakeholders working towards the SDGs (companies, public authorities and citizens) with an awareness of how the implementation of a circular economy can help them to achieve their goals. In order to do this, a table compiled by the authors allows them to visualise the impacts of the implementation of a CE for each of the 169 targets linked to the SDGs according to the three CSR pillars.

Nevertheless, this theoretical analysis based on a review of the existing literature has one major limitation: it does not assess the degree of correlation between the variables qualitatively. This points to a need for further, more empirical research to reveal the extent to which action taken to achieve the SDGs can be reinforced by the implementation of a circular economy.

Author Contributions: Conceptualization, J.-M.V. and C.A.-P.; methodology, J.-M.V. and C.A.-P.; formal analysis, J.-M.V. and C.A.-P.; investigation, J.-M.V. writing —original draft preparation, J.-M.V.; writing—review and editing, C.A.-P.; supervision, C.A.-P.; project administration, C.A.-P.; funding acquisition, C.A.-P. All authors have read and agreed to the published version of the manuscript.

Funding: Action financed by the Community of Madrid within the framework of the Multi-year Agreement with the Universidad Politécnica de Madrid in the line of action Program of Excellence for University Teaching Staff-Echegaray Grant.

Institutional Review Board Statement: Not applicable.

Informed Consent Statement: Not applicable.

Data Availability Statement: Not applicable.

Conflicts of Interest: The authors declare no conflict of interest.

\section{References}

1. Naciones Unidas. Available online: https://news.un.org/es/story/2018/03/1428291 (accessed on 10 December 2018).

2. Global Forest Watch. Available online: https://blog.globalforestwatch.org/es/data-and-research/datos-globales-de-perdida-de -cobertura-arborea-2019/ (accessed on 27 May 2018).

3. Food and Agriculture Organization of the United Nations. El Estado de La Inseguridad Alimentaria En El Mundo 2011: Como Afecta La Volatilidad de Los Precios Internacionales a Las Economías Nacionales y La Seguridad Alimentaria? Food \& Agriculture Organization of the United Nations (FAO): Rome, Italy, 2011.

4. Vilches, A.; Perez, D.G.; Toscano, J.C.; Macías, Ó. Poner fin al Agotamiento y Destrucción de los Recursos Naturales; Organización de Estados Iberoamericanos OEI: Madrid, Spain, 2014; Available online: https:/ / www.researchgate.net/publication/302414407 (accessed on 14 March 2021).

5. Pais, E.; Rivera, A. El Hombre, Responsable del Cambio Climático. Available online: https://elpais.com/diario/2007/02/03/soc iedad/1170457201_850215.html (accessed on 5 June 2018).

6. Refoyo, P.; Muñoz, B.; Polo, I.; Olmedo, C.; Requero, A. El hombre como factor de extinción biológica. Real Soc. Española Hoistoria Nat. 2013, 10, 95-104.

7. Naciones Unidas. Available online: https://www.un.org/sustainabledevelopment/es/2017/05/hasta-13-millones-de-hectareasde-bosques-desaparecen-cada-ano-por-la-accion-del-hombre/ (accessed on 5 June 2018).

8. World Wide Nature. Informe Planeta Vivo 2014; World Wide Nature: Gland, Switzerland, 2014; Available online: http:/ /awsassets. wwf.es/downloads/ipv_resumen_2014_1.pdf (accessed on 15 March 2021).

9. Haluk, E. Efficient resource allocation on the basis of priorities. Econometrica 2002, 70, 2489-2497.

10. Olcese Santoja, A.; Alfaro de la Torre, J.; Sanchez, C. La Responsabilidad Social, Motor del Cambiio Empresarial; Mcgraw-Hill: New York, NY, USA, 2014.

11. Oxford University Press. Informe Brundland; OUP: Oxford, UK, 1987.

12. Asamblea General Naciones Unidas. Transformar nuestro mundo: La Agenda 2030 para el Desarrollo Sostenible. In Proceedings of the A/RES/70/1, New York, NY, USA, 25 September 2015; Naciones Unidas: New York, NY, USA, 2015.

13. Kirchherr, J.; Reike, D.; Hekkert, M. Conceptualizing the circular economy: An analysis of 114 definitions. Resour. Conserv. Recycl. 2017, 127, 221-232. [CrossRef]

14. Gamboa Esteves, A.C. La estrategia heurística: Variante del pensamiento científico para la investigación socio-cultural. Rev. Comun. SEECI 2014, 26-34. [CrossRef]

15. Polya, G. How to Solve It; Princeton University Press: New York, NY, USA, 1945; pp. 21-31.

16. de Cajas, A.U.; Seguros, B.Y. La Economía Circular en el Sector Agroalimentario; Adicae: Brussels, Belgium, 2013.

17. Comision Europea. Iniciativa de Empleo Verde Aprovechar el Potencial de Creación de Empleo de la Economía Verde; Comision Europea: Bruselas, Belgica, 2014. 
18. World Economic Forum. Towards the Circular Economy; Accelerating the Scale-Up Across Global Supply Chains; WEF: Geneva, Switzerland, 2014.

19. Sustainable Development Goals Partnerships Platform. Available online: https://sustainabledevelopment.un.org/partnership/ $? p=29808$ (accessed on 31 December 2020).

20. European Commission. Closing the Loop, an EU Action Plan for the Circular Economy; European Commission: Brussels, Belgium, 2015.

21. European AcademiScience Advisory council. Circular Economy: A Commentary from the Perspectives of the Natural and Social Sciences; EASAC: Halle, Germany, 2015.

22. Ellen MacArthur Foundation, McKinsey Center for Business and Environment. Available online: https: / / ellenmacarthurfounda tion.org/growth-within-a-circular-economy-vision-for-a-competitive-europe (accessed on 15 March 2021).

23. European AcademiScience Advisory Council. Indicators for a Circular Economy; EASAC: Halle, Germany, 2016.

24. European AcademiScience Advisory Council. Indicators for a Circular Economy; EASAC: Halle, Germany, 2017.

25. International Water Association. Water Utility Pathways in a Circular Economy; IWA: London, UK, 2016.

26. Lewandowski, M. Designing the Business Models for Circular Economy-Towards the Conceptual Framework. Sustainability 2016, 8, 43. [CrossRef]

27. de España, G. Hacia una Estrategia Española de Desarrollo Sostenible. 2018. Available online: http:/ /www.exteriores.gob.es/Po rtal/es/SalaDePrensa/Multimedia/Publicaciones/Documents/PLAN\%20DE\%20ACCION\%20PARA\%20LA\%20IMPLEME NTACION\%20DE\%20LA\%20AGENDA\%202030.pdf (accessed on 16 March 2021).

28. Schröder, P.; Anggraeni, K.; Weber, U. The Relevance of Circular Economy Practices to the Sustainable Development Goals. J. Ind. Ecol. 2019, 23, 77-95. [CrossRef]

29. Lipińska, D. The Water wastewater sludge Sector and the Circular Economy. Comp. Econ. Res. Cent. East. Eur. 2018, 21, 121-137. [CrossRef]

30. UN Environment Programme. One Plan for One Planet; 5 Year Strategy 2018-2022; UN Environment Programme: Nairobi, Kenya, 2018.

31. Federación Española de Municipios y Provincias. Hacia una Estrategia Local de Desarrollo Sostenible; FEMP: Madrid, Spain, 2019; Available online: http:/ /www.femp.es/sites/default/files/multimedia/estrategia_local_ec_170x240_definitiva_compressed.pdf (accessed on 17 March 2021).

32. Ministerio para la Transicion Ecologica. Estrategia Española de Economía Circular; MITECO: Belgrade, Spain, 2018.

33. Morseletto, P. Targets for a circular economy. Res. Conserv. Recycl. 2020, 153, 104553. [CrossRef]

34. Sustainable Development Goal Indicator Website. Available online: https://unstats.un.org/sdgs/indicators/database/ (accessed on 17 March 2021).

35. Lieder, M.; Rashid, A. Towards circular economy implementation: A comprehensive review in context of manufacturing industry. J. Clean. Prod. 2016, 115, 36-51. [CrossRef]

36. Chen, T.-L.; Kim, H.; Pan, S.-Y.; Tseng, P.-C.; Lin, Y.-P.; Chiang, P.-C. Implementation of green chemistry principles in circular economy system towards sustainable development goals: Challenges and perspectives. Sci. Total Environ. 2020, 716, 136998. [CrossRef] [PubMed]

37. Programa Mundial de Evaluación de los Recursos Hídricos de la UNESCO (WWAP). Informe Mundial de Las Naciones Unidas Sobre el Desarrollo de Los Recursos Hídricos 2019: No Dejar a Nadie Atrás; UNESCO: Paris, France, 2019.

38. Alfarra, A.; Kemp-Benedict, E.; Seder, N.; Hötzl, H. A Framework for Wastewater Reuse in Jordan: Utilizing a Modified Wastewater Reuse Index. Water Resour. Manag. 2011, 25, 1153-1167. [CrossRef]

39. Alcalde Sanz, L.; Manfred Gawlik, B. Water Reuse in Europe. In Relevant Guidelines, Needs for and Barriers to Innovation; European Commission: Luxembourg, 2014. [CrossRef]

40. Giakoumis, T.; Vaghela, C.; Voulvoulis, N. The role of water reuse in the circular economy. Adv. Chem. Pollut. Environ. Manag. Prot. 2020, 5, 227-252. [CrossRef]

41. Stuchtey, M. Four Ways Water Can Join the Circular Economy Revolution. The Guardian. 2016. Available online: https: //www.theguardian.com/sustainable-business/2015/mar/05/water-circular-economy-revolution (accessed on 18 March 2021).

42. Dilekli, N.; Cazcarro, I. Testing the SDG targets on water and sanitation using the world trade model with a waste, wastewater, and recycling framework. Ecol. Econ. 2019, 165, 106376. [CrossRef]

43. Leyva-Díaza, J.; Monteoliva-García, A.; Martín-Pascual, J.; Munio, M.; García-Mesa, J.; Poyatos, J. Moving bed biofilm reactor as an alternative wastewater treatment process for nutrient removal and recovery in the circular economy model. Bioresour. Technol. 2020, 299, 122631. [CrossRef]

44. Mitchell, P.; James, K. Economic Growth Potential of More CE; WRAP: Banbury, UK, 2015.

45. Morgan, J.; Mitchel, P. Employment and the circular economy. In Job Creation in a More Resource Efficient Britain; Green Alliance: London, UK, 2015.

46. Jolly, C.; Douillard, P. Economie Circulaire: Combien D'emplois? France Stratégie. 2016. Available online: https://www.strategie. gouv.fr/publications/leconomie-circulaire-combien-demplois (accessed on 1 May 2021).

47. Gower, R.; Schröder, P. Virtuous Circle: How the Circular Economy Can Create Jobs and Save Lives in Low and Middle-Income Countries. Available online: https://www.tearfund.org/-/media/learn/resources/reports/2016-tearfund-virtuous-circle.pdf (accessed on 15 March 2021). 
48. Tukker, A. Eight Types of Product-Service System: Eight Ways to Sustainability? Experiences from Suspronet. Bus. Strategy Environ. 2004, 13, 246-260. [CrossRef]

49. Lobato Gago, I. Economia Circular. De la "Eco-Obligación a la Eco-Oportunidad"; Autopublicaciones Tagus: Tagus, Spain, 2017.

50. Ehrenfeld, J.; Chertow, M.R. Industrial Symbiosis: The Legacy of Kalundborg. A Handbook of Industrial Ecology. Available online: http:/ / pustaka.unp.ac.id/file/abstrak_kki/EBOOKS/A\%20Handbook\%20of\%20Industrial\%20Ecology.pdf (accessed on 1 May 2021).

51. Chertow, M.; Park, J. Scholarship and Practice in Industrial Symbiosis: 1989-2014. In Taking Stock of Industrial Ecology; Springer International Publishing: Cham, Switzerland, 2016; pp. 87-116. [CrossRef]

52. Wijkman, A.; Skånberg, K. The Circular Economy and Benefits for Society Swedish Case Study Shows Jobs and Climate as Clear Winners; The Club of Rome: New York, NY, USA, 2015.

53. Manickam, P.; Duraisamy, G. Principles of circular economy. In Circular Economy in Textiles and Apparel; Woodhead Publishing: Sawston, UK, 2018.

54. Esposito, M.; Tse, T.; Soufani, K. The Circular Economy Takes on Food Waste. Available online: https://ssir.org/articles/entry/ the_circular_economy_takes_on_food_waste (accessed on 15 March 2021).

55. Castellani, V.; Sala, S.; Mirabella, N. Beyond the Throwaway Society: A Life Cycle-BasedAssessment of the Environmental Benefit of Reuse. Integr. Environ. Assess. Manag. 2014, 11, 373-382. [CrossRef]

56. Camacho-Otero, J.; Tunn, V.; Chamberlin, L. Handbook of the Circular. Available online: https:/ / econpapers.repec.org/bookcha p/elgeebook/18519.htm (accessed on 15 March 2021).

57. Rizos, V.; Behrens, A.; van der Gaast, W.; Hofman, E.; Ioannou, A.; Kafyeke, T.; Topi, C. Implementation of Circular Economy Business Models by Small and Medium-Sized Enterprises (SMEs): Barriers and Enablers. Sustainability 2016, 8, 1212. [CrossRef]

58. Hobson, K.; Lynch, N. Diversifying and de-growing the circular economy: Radical social transformation in a resource-scarce world. Futures 2016, 82, 15-25. [CrossRef]

59. Mylan, J.; Holmes, H.; Paddock, J. Re-Introducing Consumption to the 'Circular Economy': A Sociotechnical Analysis of Domestic Food Provisioning. Sustainability 2016, 8, 794. [CrossRef]

60. Bocken, N.; Short, S.; Rana, P.; Evans, S. A literature and practice review to develop sustainable business model archetypes. J. Clean. Prod. 2014, 65, 42-56. [CrossRef]

61. Mont, O. Clarifying the concept of product-service system. J. Clean. Prod. 2002, 10, 237-245. [CrossRef]

62. Foretica. Available online: https://foretica.org/proyectos-y-soluciones/grupo-de-accion-de-economia-circular/ (accessed on 15 May 2021).

63. Ihobe. Sociedad Pública de Gestión Ambiental. In Indicadores de Economía Circular Del País Vasco 2018; Ihobe: Bilbao, Spain, 2018.

64. Alhola, K.; Olof Ryding, S.; Salmenperä, H.; Juul Busch, N. Exploiting the Potential of Public Procurement: Opportunities for Circular Economy: Public procurement promoting circular economy. J. Ind. Ecol. 2018, 23, 96-109. [CrossRef]

65. Schröder, P.S.; Antonarakis, A.; Brauer, J.; Conteh, A.; Kohsaka, R.; Uchiyama, Y.; Pacheco, P. SDG 12: Responsible Consumption and Production-Potential Benefits and Impacts on Forests and Livelihoods; Cambridge University Press: Cambridge, UK, 2019; pp. 386-418.

66. Barreiro-Gen, M.; Lozano, R. How circular is the circular economy? Analysing the implementation of circular economy in organisations. Bus. Strategy Environ. 2020, 26, 3484-3494. [CrossRef]

67. Lefèvre, C.; Rekik, F.; Alcantara, V.; Wiese, L. Carbono Orgánico del Suelo: El Potencial Oculto; Organización de las Naciones Unidas para la Alimentación y Agricultura Roma: Roma, Italia, 2017.

68. Anton Vallejo, M.A. Utilización Del Análisis de Ciclo de Vida en la Evaluación Ambiental Del Cultivo Bajo Invernadero Mediterraneo; Universidad Politécnica de Cataluña: Barcelona, Spain, 2004.

69. Agencia Europea de Medio Ambiente (AEMA). Available online: https://www.eea.europa.eu/es/senales/senales-2019/articulo s/el-suelo-la-tierra-y (accessed on 15 March 2021).

70. Espaliat Canu, M. Economia Circular y Sostenibilidad: Nuevos Enfoques Para la Creación de Valor; CreateSpace Independent Publishing Platform: Scotts Valley, CA, USA, 2019.

71. Benyus, J. Biomímesis; Como la Ciencia Innova Inspirándose en la Naturaleza; Tusquets Editores S.A.: Barcelona, Spain, 2012.

72. Naciones Unidas. Informe de los Objetivos de Desarrollo Sostenible; UN: New York, NY, USA, 2017.

73. Naciones Unidas. Informe de los Objetivos de Desarrollo Sostenible; UN: New York, NY, USA, 2018.

74. Naciones Unidas. Informe de los Objetivos de Desarrollo Sostenible; UN: New York, NY, USA, 2019.

75. Naciones Unidas. Informe de los Objetivos de Desarrollo Sostenible; UN: New York, NY, USA, 2020.

76. Lacovidou, E.; Velis, C.A.; Purnell, P.; Zwirner, O.; Brown, A.; Hahladakis, J.; Millward-Hopkin, J.T.; Williams, P. Metrics for optimising the multi-dimensional value of resources recovered from waste in a circular economy: A critical review. J. Clean. Prod. 2017, 166, 910-938. [CrossRef]

77. Figge, F.; Stevenson Thorpe, A.; Givry, P.; Franklin-Johnson, E.; Canning, L. Longevity and Circularity as Indicators of Eco-Efficient Resource Use in the Circular Economy. Ecol. Econ. 2018, 150, 297-306. [CrossRef]

78. Desrochers, P. Industrial symbiosis: The case for market coordination. J. Clean. Prod. 2004, 12, 1099-1110. [CrossRef]

79. Morel, K.; Léger, F.; Sass Ferguson, R. Permaculture. Encycl. Ecol. 2018, 4, 559-567.

80. Mollison, B.; Holmgren, D. Permaculture One: A Perennial Agricultural System for Human Settlements; Tagari Publications: Sisters Creek, Australia, 1978 
81. Haupt, M.; Hellweg, S. Measuring the environmental sustainability of a circular economy. Environ. Sustain. Indic. 2019, 1, 100005. [CrossRef]

82. Naciones Unidas. La Responsabilidad Cívica de Las Empresas en la Economía Mundial; Naciones Unidas: New York, NY, USA, 1999. 